\title{
Incidência De Carcinoma Hepatocelular Em Pacientes Cirróticos Acompanhados Em Ambulatório Terciário, De Acordo Com Sua Etiologia.
}

\author{
Comerlato, P.H.; Mattos, A.A.; John, J.A.; Porto, M.; Miozzo, S.A.S.; Silva, \\ R.R.; Contiero, P.; \\ Apresentador: Pedro Henrique Comerlato
}

\section{Resumo}

Introdução: O carcinoma hepatocelular $(\mathrm{CHC})$ é a principal neoplasia primária do fígado $(90 \%)$, sendo a cirrose, independente da sua causa, seu principal fator de risco. O objetivo do presente estudo consiste em avaliar a incidência desta neoplasia durante o acompanhamento em um ambulatório de hipertensão portal de um hospital terciário, de acordo com a etiologia da cirrose. Métodos: Foi realizado um estudo coorte, observacional e retrospectivo em todos pacientes com diagnóstico de cirrose com acompanhamento em ambulatório entre março de 2005 a março de 2010 por meio de revisão de prontuários. Foram incluídos todos os pacientes com diagnóstico de cirrose e seguimento mínimo de um ano. Foram excluídos casos de co-infecção com HIV, transplante de órgãos prévio, diagnóstico de $\mathrm{CHC}$ avançado no primeiro atendimento, ausência de registro e perda de seguimento. $O$ rastreamento de $\mathrm{CHC}$ foi realizado por exames laboratoriais (alfafetoproteína) e exames de imagem (ultrassonografia abdominal), realizados rotineiramente no seguimento ambulatorial destes pacientes. Critérios para etiologias: Vírus da Hepatite C (VHC) - anti-HCV + PCR Vírus da Hepatite B (VHB) - HBsAg + PCR Álcool - ingestão $>80 \mathrm{~g} /$ dia por 10 anos (homens) ou $40 \mathrm{~g} / \mathrm{dia}$ (mulheres) Outros - diagnóstico histológico ou por exclusão. O projeto foi aprovado pelo CEP institucional. Na comparação de variáveis categóricas utilizamos o teste do qui-quadrado. O nível de significância do estudo foi de ? $=0,05$. Os dados foram analisados com o programa SPSS 18.0. Resultados: Durante o acompanhamento do estudo, 87 pacientes (17\% de 527) desenvolveram carcinoma hepatocelular. Analisando os grupos pré-definidos foi possível observar que a incidência de CHC foi de 21\% (39 de 186) nos pacientes portadores de VHC, $13 \%$ (16 de 126) naqueles com cirrose por álcool, $20 \%$ (24 de 119) nos pacientes cuja etiologia era a combinação de VHC e álcool e 8\% (8 de 94) nos pacientes com cirrose por outras causas $(\mathrm{p}=0,02)$. Conclusão: A alta incidência de carcinoma hepatocelular demonstra a importância do rastreamento periódico para a neoplasia durante o acompanhamento ambulatorial de pacientes cirróticos. A despeito da cirrose como fator de risco isolado, verificou-se, em nossa casuística, uma maior proporção desta neoplasia em pacientes cuja etiologia da cirrose era o VHC.

\section{Referência:}

Comerlato, P.H.; Mattos, A.A.; John, J.A.; Porto, M.; Miozzo, S.A.S.; Silva, R.R.; Contiero, P.;. Incidência De Carcinoma Hepatocelular Em Pacientes Cirróticos Acompanhados Em Ambulatório Terciário, De Acordo Com Sua Etiologia.. In: II Congresso Brasileiro de Medicina Hospitalar - II CBMH [= Blucher Medical Proceedings, vol.1, num.5] São Paulo: Editora Blucher, 2014. p.44

DOI 10.5151/medpro-II-cbmh-038 